\title{
韓国の建設プロジェクトにおける分離発注のしくみに関する研究
}

韓国の建設関連法律の契約関連項目の分析を中心に

\section{A STUDY ON THE SEPARATED CONSTRUCTION PROCUREMENT SYSTEM IN KOREA}

Focusing on the analyzing the legislation of construction in Korea

\author{
趙 宰 庸*, 古阪秀三** \\ Jaeyong CHO and Shuzo FURUSAKA
}

\begin{abstract}
Although nominated subcontractor system in which an employer nominates a specialist contractor is widely used all across the world, it does not exist in Korea as separated construction procurement system in which electrical works and communication works are separately nominated is widely used.

The purpose of this study is to clarify the structure of separated construction procurement system and coordination problems that can arise through analysis of legislations related to separated construction procurement in Korea. As the result, this study elucidated that though Korea made it mandatory to separately employ electrical works and communication works to guarantee the quality of specialized works from 1970s, standards of related legal articles are different from one another. Second, the study made clear the principal agents of design work, supervision work and construction work. Lastly, study revealed the contradiction that while responsible supervision is conducted in the coordination regarding design work, supervision work and construction work for public works, general contractors conduct construction coordination in private works.
\end{abstract}

Keywords : Separate procurement, Korea, Legislation, Coordination 分離発注, 韓国, 法律, コーディネーション

1. はじめに

\section{1-1 研究の背景と目的}

専門工事業者は元請業者の下請業者として実質的に工事を分担し 1)、プロジェクトの品質確保において重要な役割を担当している ${ }^{2) 3}$ 。 しかし、専門工事業者の採用と管理の方法は各国で異なり、通常は 国ごとに法的なしくみを作っている。

専門工事業者は、締結した契約の関係や内容にしたがって、大き く一般下請業者、指定下請業者、分離発注業者に分けられる。三つ の契約方式の主な差異は問題が発生した場合の責任関係である。一 般下請業者の場合、元請業者が専門工事業者を選定・契約し、管理 の責任を持つ。しかし、指定下請業者の場合、発注者が専門工事業 者を選定し、元請業者は発注者が選んだ専門工事業者と契約を結ぶ。 この際、専門工事業者に対する管理の責任は元請業者が持つ。指定 下請制度は英国の制度の影響を受けた国と地域で普及し、下請契約 制度の一つとして使われてきた ${ }^{4)}$ これを Nominated Subcontractor 制度 (以下 NSC 制度) という。また、日本でも独自の指定下請制度と して設備分野を中心に適用されているコストオン方式などが存在し
ている ${ }^{5) 6)}$ 。一方、分離発注業者は別途工事、すなわち分離発注さ れた工事を担当する専門工事業者であり、特殊な技術分野や発注者 の要求などによって行われる工事を行うため、発注者と専門工事業 者が直接に契約を結ぶ。

しかし韓国ではこのような指定下請制度はない。韓国の場合、専

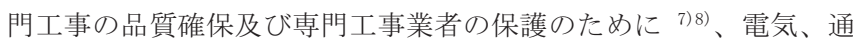
信の特殊工事を分離して発注する分離発注方式の適用が義務化され ている 7)89911011112)。したがって韓国で NSC 制度が適用されていない 状況を理解寸るためには、現在用いられている分離発注のしくみを 明確にし、その特徵、とりわけ契約関係や内容とその問題点を明ら かにする必要がある。

以上の背景にしたがって本稿では、韓国の分離発注に関する法律 項目の分析に基づいて、韓国で適用されている分離発注方式のしく みを明確にし、主体間の関係と責任の配分を考察することを目的と する。

\section{1-2 研究の範囲と方法}

(1) 研究範囲：分析対象法律

\footnotetext{
* 京都大学大学院工学研究科建築学専攻 博士課程 $\cdot$ 工修

Ph. D. Candidate, Dept. of Architecture and Architectural Eng., Graduate School of Eng., Kyoto Univ., M. Eng.

** 京都大学大学院工学研究科建築学専攻 教授.工博

Prof., Dept. of Architecture and Architectural Eng., Graduate School of Eng., Kyoto Univ., Ph. D. Eng.
} 
本稿では、プロジェクトの分離発注に関する韓国の法律として建 設工事に関する法律である建築法、建設産業基本法、建設技術振興 法 ((旧) 建設技術管理法)、国家契約法、建築士法、電気工事に関す る電気工事業法、電力技術管理法、情報通信工事 (以下、通信工事) に関する情報通信工事業法、消防工事に関する消防施設工事業法を 対象とする。表 1 は韓国での、プロジェクトの分離発注に関連した 法律名と、その法律に明記された目的を示したものである。

\section{表 1 韓国における建築工事に関わる法律}

\begin{tabular}{|c|c|}
\hline & 法律名と目的 \\
\hline \multirow{6}{*}{$\begin{array}{l}\text { 建築 } \\
\text { 工事 }\end{array}$} & (1) 建築法 (1962 年制定、2015 年改正) \\
\hline & 建築物の土地·構造·設備寻 \\
\hline & $\begin{array}{l}\text { (2) 建設産業基本法(1958 年制定、2014 年改正) } \\
\text { 建設工事の調査、設計、施工、監理注 } 1 \text { 、維持管理、技 } \\
\text { 術管理などに関する基本的な事項と建設業の登録、建設 } \\
\text { 工事の請負等に必要な事項を定める。 }\end{array}$ \\
\hline & $\begin{array}{l}\text { (3) 建設技術振興法 (1987 年制定、 } 2015 \text { 年改正) } \\
\text { 建設技術の研究·開発を促進して建設技術水準を向上さ } \\
\text { せることで建設業を振興し、建設工事が適正に実施され } \\
\text { るとともに、建設工事の品質を高める。 }\end{array}$ \\
\hline & $\begin{array}{l}\text { (4) 国家契約法(1995 年制定、2014 年改正) } \\
\text { 国家を当事者とする契約に関する基本的な事項を定め } \\
\text { る。 }\end{array}$ \\
\hline & $\begin{array}{l}\text { (5) 建築士法 (1963 年制定、2015 年改正) } \\
\text { 建築士の資格と、その業務に関する事項を定める。 }\end{array}$ \\
\hline \multirow{3}{*}{$\begin{array}{l}\text { 電気 } \\
\text { 工事 }\end{array}$} & (6) 電気工事業法 (1963 年制定、2013 年改正) \\
\hline & $\begin{array}{l}\text { 電気工事業と電気工事の施工·技術管理及び請負に関す } \\
\text { る基本的な事項を定める。 }\end{array}$ \\
\hline & $\begin{array}{l}\text { (7) 電力技術管理法 (1995 年制定、2014 年改正) } \\
\text { 電力技術の研究·開発を促進し、これを効率的に利用·管 } \\
\text { 理することにより、電力技術を高める。 }\end{array}$ \\
\hline 通信 & (8) 情報通信工事業法 (1971 年制定、2014 年改正) \\
\hline 工事 & $\begin{array}{l}\text { 通信工事の調查·設計·施工·監理·維持管理·技術管理な } \\
\text { どに関する基本的な事項と通信工事業の登録及び通信 } \\
\text { 工事の請負等に必要な事項を定める。 }\end{array}$ \\
\hline 消防 & (9) 消防施設工事業法 (2003 年制定、2014 年改正) \\
\hline 工事 & $\begin{array}{l}\text { 消防施設工事及び消防技術の管理に必要な事項を定め } \\
\text { る。 }\end{array}$ \\
\hline
\end{tabular}

(出所 : 筆者作成)

\section{（2）研究方法}

韓国の建築プロジェクトにおける分離発注制度のしくみを把握す るため、表 1 の法律を対象に分離発注制度の構成と特徵を分析する。 次に、分離発注制度に関わる法律で定義されている主体間の業務関 係を分析し、設計、監理、施工などにおける業務間調整（以下、コー ディネーション)の状況を明らかにし、その問題点を考察する。

\section{1-3 既往研究の考察}

韓国の分離発注方式に関する研究は、韓国における建設業のみな らず、電気、通信、消防などの様々な分野で行われている。 $\mathrm{Kim}^{9}{ }^{9}$ は 現場管理者を対象とするアンケート分析から、現場のトラブルの一 因として、電気設備の分離発注を挙げた。Lee ${ }^{7}$ は、総合工事業者が 施工全体を担当する場合の問題点を指摘し、消防工事の分離発注の 妥当性を述べた。 $\mathrm{Kim}^{8}{ }^{8}$ は電気工事分離発注に関して政策面での分析
を行った。Chang ${ }^{10)}$ は分離発注の問題点をまとめ、その管理を行う役 割として CM の導入を主張した。Kim ${ }^{11}$ はヒアリング調查を通じて、 建設業における主体別の分離発注に対する意見をまとめた。Jo ${ }^{12)}$ は 韓国のゼネコンを対象にアンケート調査を実施し、最も不公平な契 約条件として分離発注業者に対するゼネコンの包括的責任を挙げた。

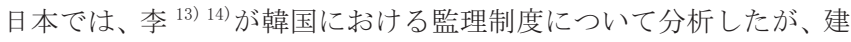
設工事に限られている。

以上のように韓国における分離発注方式に関する長所、短所を扱 っている研究は多いが、それぞれの法律上のしくみの比較とコーデ ィネーションの関係を扱う研究は少ないのが実情である。

\section{2. 韓国の建設業と分離発注方式}

\section{2-1 分離発注方式}

分離発注方式とは、発注者が様々な工事を担当する専門工事業者 と直接に契約関係を結 ぶ発注方式である ${ }^{15)}$ 。 これにより、分離発注 方式では、発注者が希 望する業者を選択する ことができる。また、 この方式では元請業者 を介さないため、元請 業者が専門工事業者を 管理するための費用が 生じない10)。しかしこ の方式では、発注者が

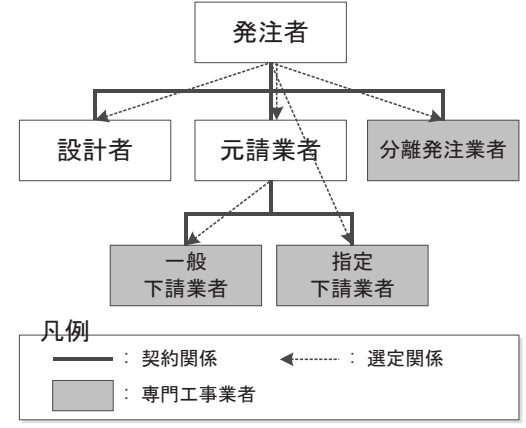

図 1 分離発注方式の構造

(出所：Hinze $\mathrm{e}^{15)}$ に基づいて筆者作成) 各々の専門工事業者を管理する業務を担当するため、プロジェクト を管理する能力、並びに組織が発注者側に要求される ${ }^{15)}$ 。一方、専 門工事業者の立場としては、発注者と直接に契約関係を持つため、 総合工事業者と対等な関係となり、公平な取引が期待できる ${ }^{7)}$ 。

\section{2-2 韓国における建築資格制度}

1999 年、世界貿易機関(World Trade Organization) は国際建築家 連盟(International Union of Architects) を通じて建築専門職(建 築士)の基準 ${ }^{16)}$ を作成した。韓国はこの基準を導入し、2002 年から 建築学部を 5 年制の建築学科と 4 年制の建築工学科の二つに分離し た。現在、韓国の大学では、建築学科と建築工学科が完全に分離さ れた 2 つの学科として存在する大学と、 1 年生までは建築学部とし て入学し、2 年生になる時に建築学科と建築工学科に分かれる大学 が存在する。建築学科では、建築士に代表される意匠設計を中心に 教育し、建築工学科では、技術士に代表される建築構造、建築施工 などを中心に教育している。

\section{(1) 建築士 ${ }^{17)}$}

建築士は建物の設計と監理を担当する主体であり、国家専門資格 として分類される。建築士に関しては建築士法に規定されている。 建築士になるためには、まず、建築士予備になる必要がある。建築 士予備試験は、高校、短大、大学 (5 年)を卒業し、それぞれに定め られた実務経験の期間を経た後、受けることができる。建築士予備 は、 4 年の実務経験の後、建築士試験を受けることができる。建築 工学の分野の技士資格を獲得した者は 3 年の実務経験、技術士を取 得した者は、追加実務経験なしに建築士試験を受けることができる。 
建築士は建築界固有の資格である(図 2)。

(2) 技術士 ${ }^{17)}$

技術士は建設業のみならず、電気、通信、機械などの様々な技術 分野の国家技術資格 (技能士、産業技士、技士、技術士)の一つであ り、国家技術資格の中で最も上位の資格として、建設技術振興法、 国家技術資格法などに規定されている。技術士の試験は技士の資格

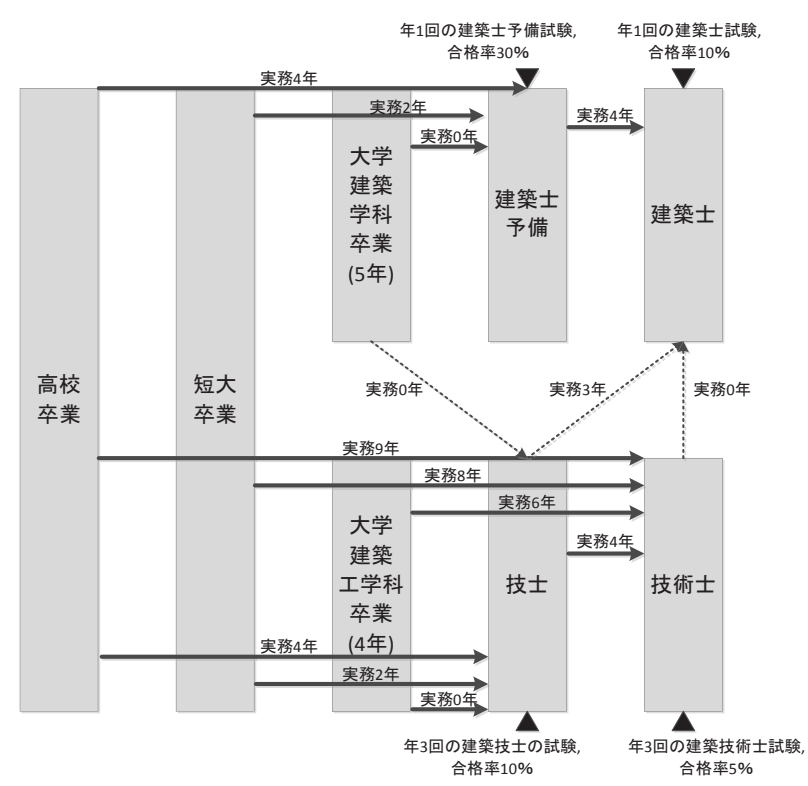

図 2 韓国における建設資格試験制度

(出所：筆者作成)

を持っていることを条件としていない(図 2)。

2-3 韓国における建設業種の分類

(1) 建設業種の分類と関連法

韓国の法律における建設業は、施工を担当する業種を意味し、総

\begin{tabular}{|c|c|c|c|c|}
\hline \multicolumn{3}{|c|}{ 業種分類 } & 関連法 & 管轄 \\
\hline \multirow{10}{*}{ 建設業 } & \multirow{5}{*}{$\begin{array}{c}\text { 総合建設業 } \\
\text { (5種) }\end{array}$} & 1. 土木建築工事業 & \multirow{10}{*}{ 建設産業基本法 } & \multirow{10}{*}{ 国土交通部 } \\
\hline & & 2. 土木工事業 & & \\
\hline & & 3. 建築工事業 & & \\
\hline & & 4. 産業環境設備工事業 & & \\
\hline & & 5. 造園工事業 & & \\
\hline & \multirow{5}{*}{$\begin{array}{l}\text { 専門建設業 } \\
(29 \text { 種) }\end{array}$} & 1. 室内建築工事業 & & \\
\hline & & 2. 土工事業 & & \\
\hline & & 3. 左官·防水·組積工事業 & & \\
\hline & & $\vdots$ & & \\
\hline & & 29. 施設維持管理業 & & \\
\hline 電気業 & 電気工事業 & & 電気工事業法 & 産業通商資源部 \\
\hline 情報通信業 & 通信工事業 & & 情報通信工事業法 & 未来創造科学部 \\
\hline 消防業 & 消防工事業 & & 消防施設工事業法 & 国民安全処 \\
\hline \multirow{8}{*}{$\begin{array}{c}\text { エンジニアリング } \\
\text { 産業 }\end{array}$} & 建筑設計業 & & 建築士法 & \multirow{2}{*}{ 国土交通部 } \\
\hline & 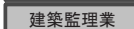 & & 建設技術管理法 & \\
\hline & 電力施設設計業 & & \multirow{2}{*}{ 電力技術管理法 } & \multirow{2}{*}{ 産業通商資源部 } \\
\hline & 電力施設監理業 & & & \\
\hline & 情報通信設計業 & & \multirow{2}{*}{ 情報通信工事業法 } & \multirow{2}{*}{ 未来創造科学部 } \\
\hline & 情報通信監理業 & & & \\
\hline & 消防施設設計業 & & \multirow{2}{*}{ 消防施設工事業法 } & \multirow{2}{*}{ 国民安全処 } \\
\hline & 消防施設監理業 & & & \\
\hline \multicolumn{5}{|l|}{ 凡例 } \\
\hline
\end{tabular}

図 3 韓国における建設業種分類

（出所 : 筆者作成）
合建設業と専門建設業が該当する(図 3)。また、建設産業は、設計、 監理、施工などの建設に関わる業種を意味し、建設業、建築設計業、 建築監理業が該当する。ここで、電気工事、通信工事、消防工事に 関する設計、監理、施工は法律上の建設産業に含まれない。韓国で は、各業種ごとに法律も分けられており、設計、監理、施工に関す る免許および登録制度などは、個別の法律によって一定の資格基準 を要求している。

まず、建設産業基本法に総合建設業と専門建設業が建設業として、 さらに建設業、建築設計業、建築監理業を合わせて建設産業として 規定されている。また、電気工事業、通信工事業、消防設備工事業 はそれぞれの法律により規定されている。

また、研究、企画、実現可能性調查、設計、分析、契約、購入、 調達、テスト、監理、試験運転、評価、検査、安全性の検討、管理、 マニュアル作成、アドバイス、指導、維持または保守に関連寸る業 種はエンジニアリング産業振興法でエンジニアリング産業として規 定されており、建築設計業は建築士法、建築監理業は建設技術振興 法で規定されている。電力設備の設計業と監理業は電力技術管理法、 通信設備の設計業と監理業は情報通信工事業法、消防施設の設計業 と監理業は消防施設工事法で規定されている。

\section{（2）業種に関する特殊な規定}

韓国の建設産業における業種分類に関する特徵的な規定は、以下 の 4 つである。

(1) 建築設計業と建築施工業の兼業禁止

建築設計業は建築士法によって施工との兼業が制限されている。 建築士法第 4 条により、建築法に基づく建築物の設計と工事監理は 建築士のみ行うことができると業種制限が明示されている。また、 建築士法第 23 条では、社名の末尾が「建築士事務所」であり、その 代表が建築士である場合にのみ、建築物の設計と工事監理を行うこ とが明記されている(1984 年改正)。したがって、総合建設業および 専門建設業に登録している限り、たとえ建築士が所属していたとし ても、その業者は建築物の設計と工事監理を行うことはできない。

(2) 総合工事業者の専門工事受注の禁止

建設産業基本法では専門工事業者を保護するため、総合工事業者 が工事の一部を専門工事業の免許を持っている総合工事業者に下請 することを禁止している(1969 年改正)。したがって、総合工事業者 が専門工事業の免許を取得することはなく、専門工事は専門工事業 者間の競争になる。

\section{(3) 二次下請の禁止}

建設産業基本法第 29 条では、下請された専門工事を二次下請業者 に再下請することを禁止している(1996 年改正)。これにより、重層 下請構造によって専門工事業者が低い工事費で工事を行うことを防 止している。

(4) 電気工事、通信工事の分離発注義務化

建設産業基本法第 2 条による建設工事は土木工事、建築工事、産 業設備工事、造園工事とそれに含まれている機械設備工事を意味し、 電気工事業法に基づく電気工事、情報通信工事業法による通信工事、 消防施設工事業法に基づく消防工事は、建設工事に含まれない(1996 年改正)。また、電気工事事業法第 11 条、情報通信工事業法第 25 条の規定により電気工事と通信工事は、他の工種との分離発注を義 務付けている。これにより、電気工事業者との通信工事業者の独立 
性を確保し、低価格契約による手抜き工事を防止している。

3. 韓国における分離発注のしくみ

\section{3-1 分離発注の法律項目}

\section{(1) 分離発注の法的根拠}

建設契約における分離発注は国家契約法に基づいている(表 2)。 国家契約法第 68 条では、一つの工事の業務を分割して契約すること を禁止している。しかし、他の法律に分離発注することが決められ ている工事(第 68 条 1)、分離発注が効率的だと判断できる工事(第 68 条 2)、瑕疪責任が明確で、全体工程管理に影響がなく、別途の設 計図書がある工事(第 68 条 3) は分離発注できると規定している。

\section{表 2 韓国におけるエ事に関連する法}

\begin{tabular}{|c|c|c|}
\hline 基本条項 & 例外条項 (分離発注可) & 当該工事 \\
\hline \multirow[t]{3}{*}{$\begin{array}{l}\text { 国家契約法 } \\
\text { 第 } 68 \text { 条 } \\
\text { 分離発注の禁止 }\end{array}$} & $\begin{array}{l}\text { 第 } 68 \text { 条 } 1 \\
\text { 他法に分離発注することが決められて } \\
\text { いる工事 }\end{array}$ & \begin{tabular}{|l} 
電気工事 \\
通信工事
\end{tabular} \\
\hline & $\begin{array}{l}\text { 第 } 68 \text { 条 } 2 \\
\text { 分離発注が効率的な工事 }\end{array}$ & - \\
\hline & \begin{tabular}{|l} 
第 68 条 3 \\
层疵責任が明確で、全体工程管理に影 \\
響がなく、別途の設計図書がある工事
\end{tabular} & 消防工事 \\
\hline
\end{tabular}

（出所：法条項に基づいて筆者作成）

電気工事は電気工事業法と電力技術管理法に従う。電気工事の設 計は電気技術士が作成すること (1995 年) 、施工は分離発注が義務化 (1976 年)されているため、電気工事は設計と施工の両方が建設工事 から分離されている。通信工事は、情報通信工事業法で規定されて おり、設計は建築士が行うが、施工は他の工種と分離発注しなけれ ばならない(1971 年)。消防工事は消防施設工事業法で規定されてお り、設計は消防技術士が作成するが、施工の分離発注項目は存在し ない。上記のような根拠条項から、電気工事と通信工事は分離発注 されており、消防工事は国家契約法第 68 条 3 項に基づき、消防関連 団体によって分離発注が推進されている(表 3)。

表 3 電気/通信/消防工事の施エと設計に関する法律

\begin{tabular}{|c|c|c|c|}
\hline & 電気工事 & 通信工事 & 消防工事 \\
\hline $\begin{array}{l}\text { (施工離発注) } \\
\text { ( }\end{array}$ & $\begin{array}{l}\text { [電気工事業法第 } \\
22 \text { 条] } \\
\text { (1)電気工事は、他 } \\
\text { の工事と分離発注 } \\
\text { しなければならな } \\
\text { い。(1976. } 12 \text { 改正) }\end{array}$ & $\begin{array}{l}{[\text { 電信電話設備工 }} \\
\text { 事業法第 } 13 \text { 条 }] \\
\text { 工事は、他の工事 } \\
\text { と分離発注しな } \\
\text { ければならない。 } \\
(1971.1 \text { 制定 })\end{array}$ & なし \\
\hline 設計 & $\begin{array}{l}\text { [電力技術管理法 } \\
\text { 第 } 11 \text { 条(1)] } \\
\text { 電力施設の設計図 } \\
\text { 書は、電気分野の } \\
\text { 技術士が作成しな } \\
\text { ければならない。 } \\
\text { (1995.12 制定) }\end{array}$ & {$\left[\begin{array}{l}{[\text { 情報通信工事業 }} \\
\text { 法第 } 2 \text { 条 } 8] \\
\text { 設計は工事計画 } \\
\text { 書、設計図面、仕 } \\
\text { 様書、工事費明細 } \\
\text { 書、技術計算書に } \\
\text { 関連する書類を } \\
\text { 作成する行為を } \\
\text { 意味する。ただ } \\
\text { し、建築士法第 } 4 \\
\text { 条の規定による } \\
\text { 建築物の建築等 } \\
\text { は除く。 } \\
\text { (1997.8 改正) }\end{array}\right.$} & $\begin{array}{l}{[\text { [消防施設工事業 }} \\
\text { 法第 } 11 \text { 条(1)] } \\
\text { 消防施設設計業 } \\
\text { を登録した者は、 } \\
\text { の法律に基づ } \\
\text { いて消防施設を } \\
\text { 設計しなければ } \\
\text { ならない。 } \\
\text { (2003.5 制定) }\end{array}$ \\
\hline
\end{tabular}

(2) 発注方式
前述した法律に基づいた韓国における設計施工分離発注方式 (Design Bid Build、以下 DBB) は、図 4 のようになる。電気工事と 通信工事の施工は本工事と分離発注されており、消防工事は下請業 者になる。設計においては、電気技術士、消防技術士が各々の図面 を作成する。しかし、電気技術士と消防技術士の資格を持っている 総合建築士事務所では、それの設計を一括して担当することもでき る。

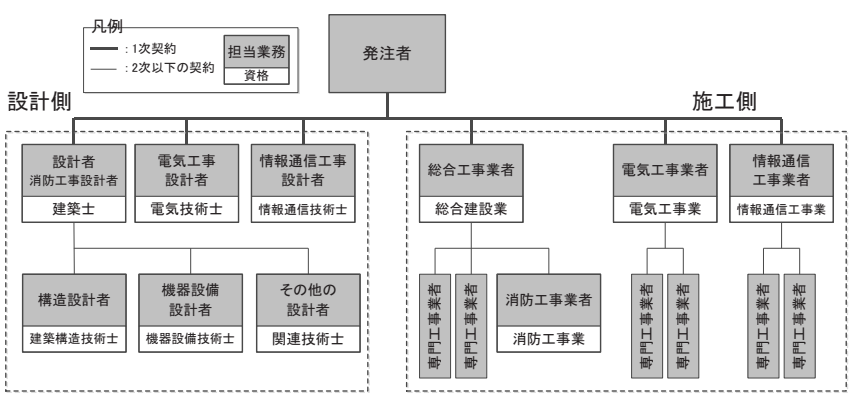

図 4 韓国における設計施工分離 (DBB) 発注方式

(出所 : 筆者作成)

設計施工一括発注方式 (Design Build、以下 DB) は図 5 のように なる。設計施工一括発注方式での設計者は、総合工事業者(ターンキ 一業者) と下請契約を結んでおり、電気工事事業、通信工事業者、消 防工事業者は総合工事業者(ターンキー業者)の下請業者になる。

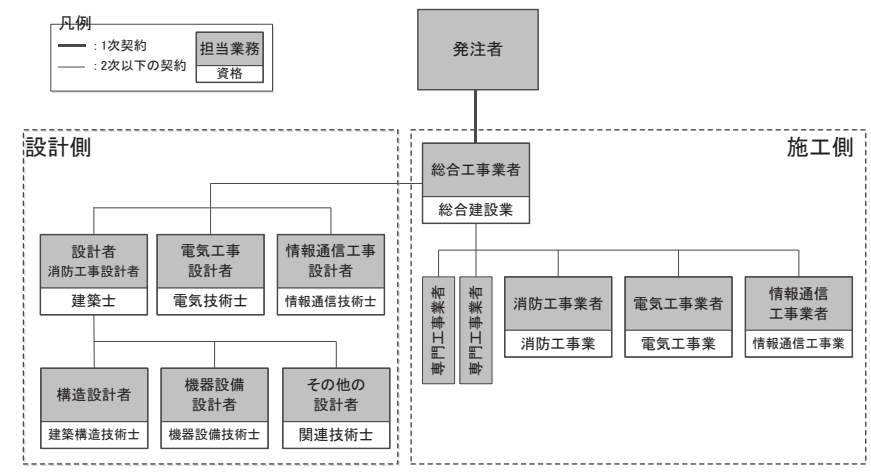

図 5 韓国における設計施エ一括 (DB) 発注方式

(出所 : 筆者作成)

しかし、図 5 のような発注方式は電気工事と通信工事が法律で規 定されている分離発注の項目と矛盾しているという点から、それぞ れの団体は次の図 6 のような改善案を要求している。

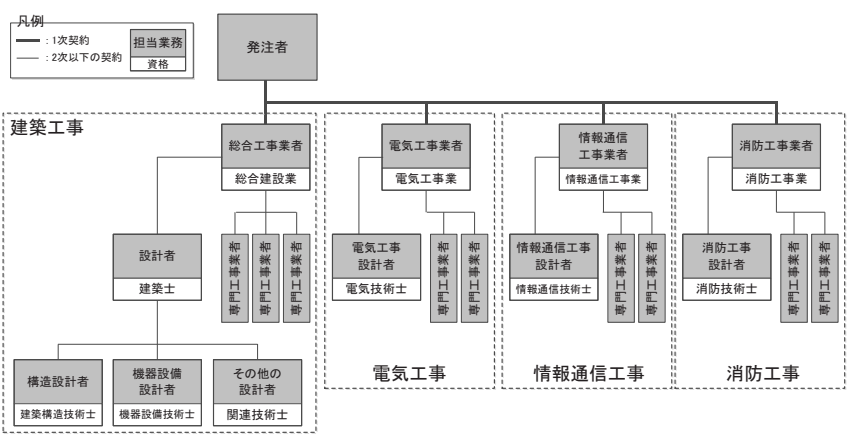

図 6 韓国における設計施エー括 (DB) 発注方式 (分離発注型)

(出所 : 筆者作成)

\section{3-2 法律条項の比較}

電気工事業、通信工事業、消防工事業は、建設産業基本法に基づ 
表 4 各法律規定の比較

\begin{tabular}{|c|c|c|c|c|}
\hline & 建設工事 & 電気工事 & 通信工事 & 消防工事 \\
\hline $\begin{array}{l}\text { 工事業の } \\
\text { 登録 }\end{array}$ & $\begin{array}{c}\text { [建設産業基本法第 } 8 \text { 条 }] \\
\text { 国土交通部に登録 } \\
3 \text { 年ごとに更新 }\end{array}$ & $\begin{array}{c}\text { [電気工事業法第 } 4 \text { 条 }] \\
\text { 市/道に登録 } \\
5 \text { 年ごとに更新 }\end{array}$ & $\begin{array}{c}\text { [通信工事業法第 } 14 \text { 条] } \\
\text { 市/道に登録 } \\
3 \text { 年ごとに更新 }\end{array}$ & $\begin{array}{c}\text { [消防施設業法第 } 4 \text { 条］ } \\
\text { 市/道に登録 }\end{array}$ \\
\hline $\begin{array}{l}\text { 分離発注の } \\
\text { 義務化 }\end{array}$ & X & $\begin{array}{c}\text { [電気工事業法第 } 11 \text { 条 }] \\
0\end{array}$ & $\begin{array}{c}\text { [通信工事業法第 } 25 \text { 条] } \\
0\end{array}$ & X \\
\hline $\begin{array}{l}\text { 下請の } \\
\text { 制限 }\end{array}$ & $\begin{array}{c}\text { [建設産業基本法第 } 29 \text { 条] } \\
2 \text { 次下請の禁止 }\end{array}$ & $\begin{array}{c}\text { [電気工事業法第 } 14 \text { 条] } \\
\text { 電気機材の納品と設置をまと } \\
\text { める場合可 } \\
\end{array}$ & $\begin{array}{c}\text { [通信工事業法第 } 31 \text { 条］ } \\
\text { 契約金額の } 50 \% \text { まで下請可 }\end{array}$ & $\begin{array}{c}\text { [消防施設業法第 } 22 \text { 条] } \\
1 \text { 回の夕可 }\end{array}$ \\
\hline $\begin{array}{l}\text { 瑕疪担保責任 } \\
\text { の期間 }\end{array}$ & $\begin{array}{c}\text { [建設産業基本法第 } 28 \text { 条 }] \\
1-10 \text { 年 } \\
\end{array}$ & $\begin{array}{c}\text { [電気工事業法施行令第 } 11 \text { 条 } \\
2 \text { 項] } \\
1 \text { 年 } \\
\end{array}$ & $\begin{array}{c}\text { [通信工事業法施行令第 } 37 \text { 条 }] \\
1 \text { 年 } \\
\end{array}$ & $\begin{array}{c}\text { [消防施設業法施行令第 } 16 \text { 条 }] \\
\qquad 2-3 \text { 年 } \\
\end{array}$ \\
\hline 現場責任者 & $\begin{array}{c}\text { [建設産業基本法第 } 40 \text { 条］ } \\
\text { 建設技術者 }\end{array}$ & $\begin{array}{c}\text { [電気工事業法第 } 16 \text { 条］ } \\
\text { 電気工事技術者 }\end{array}$ & $\begin{array}{c}\text { [通信工事業法第 } 33 \text { 条］ } \\
\text { 通信技術者 }\end{array}$ & $\begin{array}{c}\text { [消防施設業法第 } 12 \text { 条 }] \\
\text { 消防技術者 }\end{array}$ \\
\hline \begin{tabular}{|l|} 
現場責任者の \\
兼職禁止
\end{tabular} & X & $x$ & $\begin{array}{c}\text { [通信工事業法第 } 40 \text { 条］ } \\
2 \text { つ以上の見場に兼職禁止 }\end{array}$ & $x$ \\
\hline 設計 & $\begin{array}{c}\text { [建築士法第 } 4 \text { 条] } \\
\text { 建築士のみ }\end{array}$ & $\begin{array}{c}\text { [電力技術管理法第 } 11 \text { 条] } \\
\text { 電気の技術士 } \\
\text { 電力施設設計業の登録 } \\
\end{array}$ & $\begin{array}{c}\text { [通信工事業法第 } 17 \text { 条 }] \\
\text { 通信資格保有 } \\
\text { 技術士事務所 }\end{array}$ & $\begin{array}{l}\text { [消防施設業法第 } 11 \text { 条] } \\
\text { 消防施設設計業の登録 }\end{array}$ \\
\hline 監理 & $\begin{array}{c}\text { [建築法第 } 25 \text { 条] } \\
\text { 建設監理業の登録 } \\
\text { 建築士 }\end{array}$ & $\begin{array}{c}\text { [電力技術管理法第 } 14 \text { 条］ } \\
\text { 電力施設監理業の登録 }\end{array}$ & $\begin{array}{c}\text { [通信工事業法第 } 8 \text { 条] } \\
\text { 通信資格保有 } \\
\text { 技術士事務所 }\end{array}$ & $\begin{array}{l}\text { [消防施設業法第 } 16 \text { 条] } \\
\text { 消防施設監理業の登録 }\end{array}$ \\
\hline
\end{tabular}

（出所：法条項に基づいて筆者作成）

表 5 着エ/竣エに関する項目の比較

\begin{tabular}{|c|c|c|c|c|}
\hline & 建設工事 & 電気工事 & 通信工事 & 消防工事 \\
\hline 着工申告 & $\begin{array}{l}\text { [建築法第 } 21 \text { 条] } \\
\text { 自治体の公務員 }\end{array}$ & $\begin{array}{c}\text { [建築法施行令第 } 14 \text { 条 }] \\
\text { 自治体の公務員 }\end{array}$ & $\begin{array}{c}\text { [建築法施行令第 } 14 \text { 条] } \\
\text { 自治体の公務員 }\end{array}$ & $\begin{array}{c}\text { [消防施設業法施行規則第 } \\
12 \text { 条 }] \\
\text { 管轄消防署長 }\end{array}$ \\
\hline 竣工検査 & $\begin{array}{c}\text { [建築法第 } 22 \text { 条] } \\
\text { 自治体の公務員 }\end{array}$ & $\begin{array}{c}\text { [電気事業法第 } 63 \text { 条］ } \\
\text { 自治体の公務員 }\end{array}$ & $\begin{array}{c}\text { [通信工事業法第 } 36 \text { 条］ } \\
\text { 自治体の公務員 }\end{array}$ & $\begin{array}{c}\text { [消防施設業法施行規則第 } \\
13 \text { 条 } \\
\text { 管轄消防署長 }\end{array}$ \\
\hline
\end{tabular}

（出所：法条項に基づいて筆者作成）

表 6 処罰に関する項目の比較

\begin{tabular}{|c|c|c|c|c|}
\hline & 建設工事 & 電気工事 & 通信工事 & 消防工事 \\
\hline 未登録者の施工 & $\begin{array}{c}\text { [建設産業基本法第 } 96 \text { 条 }] \\
3 \text { 年以下の懲役又は } \\
3000 \text { 万ウォンン以罰金 }\end{array}$ & $\begin{array}{c}\text { [電気工事業法第 } 42 \text { 条 } 1 \text { 項 }] \\
1 \text { 年以下の懲役又は } \\
1000 \text { 万ウォンン以罰金 }\end{array}$ & $\begin{array}{c}\text { [通信工事業法第 } 74 \text { 条 }] \\
3 \text { 年以下の懲役又は } \\
2000 \text { 万ウォンン以罰金 }\end{array}$ & \begin{tabular}{|c|} 
[消防施設業法第 35 条 $]$ \\
3 年以下の懲役又は \\
1500 万ウォンツ罰金
\end{tabular} \\
\hline 分離発注の違反 & $x$ & $\begin{array}{c}\text { [電気工事業法第 } 43 \text { 条 } 4 \text { 項] } \\
500 \text { 万ウォン以下罰金 }\end{array}$ & $\begin{array}{c}\text { [通信工事業法第 } 76 \text { 条 } 4 \text { 項 }] \\
500 \text { 万ウォン以下の罰金 }\end{array}$ & 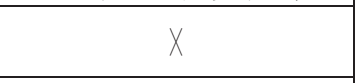 \\
\hline 専門監理員の未配置 & $\begin{array}{c}\text { [建築法第 } 110 \text { 条] } \\
2 \text { 年以下の懲役又は } \\
1000 \text { 万ウォン以下の罰金 }\end{array}$ & $\begin{array}{c}\text { [電力技術管理法第 } 30 \text { 条 } 2 \\
\text { 項] } \\
200 \text { 万ウォン以下罰金 } \\
\text { 万人地 }\end{array}$ & \begin{tabular}{|c} 
[通信工事業法第 76 条 6 項] \\
500 万ウォン以下の罰金
\end{tabular} & {$\left[\begin{array}{c}{[\text { 消防施設 業法第 } 37 \text { 条 } 2 \text { 項] }} \\
300 \text { 万ウウォン以下の罰金 }\end{array}\right.$} \\
\hline
\end{tabular}

（出所：法条項に基づいて筆者作成）

く別途工事の建設業種に分類されないため、その業種の工事は建設 産業基本法や建設技術振興法が適用されない。本項では建設工事、 電気工事、通信工事、消防工事のしくみを構成している項目を取り 上げ、比較分析する。

\section{(1) 構造に関する項目}

工事業の登録に関しては、建設業は国土交通部に登録し、電気工 事・通信工事・消防工事は各市・道に登録する。また、分離発注を 義務づける項目は、前述した電気工事と通信工事のみに存在する。

下請に関しては、建設工事では 2 次下請を禁止しているにもかか わらず、電気工事では特定の電気記載を納品した業者が設置工事も 担当する際には下請することができ、通信工事の場合、契約金額の $50 \%$ まで下請できる。また、消防工事は 1 回に限って下請できる。 電気、通信、消防工事の瑕疪担保責任期間は、建設工事に比べて短 い。設計と監理に関しては、建設工事は建築士が担当することに比 べて、電気、通信、消防工事はそれぞれの専門技術者が担当する。
構造に関する項目をまとめると表 4 のようになる。

\section{（2）着エ/竣エに関する項目}

着工申告および竣工時に使用許諾に関しても建設、電気、通信工 事と消防工事が異なっている(表 5)。建設、電気、通信工事に関し ては、建築主が自治体の公務員に届けを提出するが、消防工事は、 着工申告および竣工時に使用許諾に関して管轄の消防署長に届け出 ることになっている。

\section{（3）処罰に関する項目}

工事の中で処罰対象となる行為が発生した場合、表 6 のように、 法律に規定された処罰が下される。ここで、処罰に関しても各工事 によって基準が異なる。未登録者が工事を行った場合、建設工事は 3 年以下の懲役又は 3000 万ウォン以下の罰金に当たるが、電気、通 信、消防工事の場合は、建設工事に比べて軽い処罰になる。専門監 理員を配置していない場合、建設工事は 2 年以下の罰金または 1000 万ウォン以下の罰金に当たるが、電気、通信、消防工事の場合、比 
較的軽い処罰になる。電気工事と通信工事の分離発注を行わなかっ た場合には、500万ウォン以下の罰金の対象となる。

\section{4. 業務及びコーディネーション主体の分析 \\ 4-1 業務の担当主体}

ここでは、関連法令の分析を通じて、設計、監理、施工の業務を 担当する主体を分析する。

\section{(1) 設計業務}

建築士は建築士法第 4 項により建築物の設計図面を作成し、同法 第 21 項で設計図書に署名すると規定されている。しかし、建築法施 行令第 91 条 3 項に基づいて 6 階以上の建築物の場合は、建築構造技 術士が設計図書の作成を支援し、押印しなければならない。また、 ガス、給排水、換気、暖房、エレベーターが含まれている延べ面積 1 万平方メートル以上の建物の場合は、機器設備技術士が設計図書 の作成を支援し、押印しなければならない。建設産業基本法で建築 工事に含まれていない電気、消防工事については、それぞれの技術 士が主導的に設計図書を作成するが、建築士も当設計図書を検討し、 押印しなければならない。通信工事は情報通信工事業法第 2 条に通 信工事が建築士法第 4 条に該当する建築工事に含まれる場合、建築 一般設計の基準に従うことを規定しているため、建築士が行う。設 計業務に関する各主体の担当範囲を整理すると表 7 になる。

表 7 設計の主体とコーディネーション

\begin{tabular}{|c|c|c|c|c|c|c|c|c|}
\hline & & 建箖士 & $\begin{array}{c}\text { 建筑構造 } \\
\text { 技術士 }\end{array}$ & $\begin{array}{l}\text { 電気設備 } \\
\text { 技術士 }\end{array}$ & $\begin{array}{l}\text { 機械設㣁 } \\
\text { 技術士 }\end{array}$ & $\begin{array}{l}\text { 情粄通信 } \\
\text { 技通土 }\end{array}$ & $\begin{array}{l}\text { 消防 } \\
\text { 技政士 }\end{array}$ & 根拠法令 \\
\hline \multirow{6}{*}{ 設計 } & 建築一般 & & - & - & - & - & - & $\begin{array}{c}\text { 建築士法 } \\
\text { 第21条 }\end{array}$ \\
\hline & 構造 & & ? & - & - & - & - & $\begin{array}{l}\text { 建築法施行令 } \\
\text { 第91条の311) }\end{array}$ \\
\hline & 電気 & & & $\rightarrow 0$ & - & - & - & $\begin{array}{l}\text { 電力技術管理法 } \\
\text { 第111条(1) }\end{array}$ \\
\hline & 機械 & $<4$ & & & P & - & - & $\begin{array}{l}\text { 建築法施行令 } \\
\text { 第91条の3(2) }\end{array}$ \\
\hline & 通信 & 0 & - & - & - & - & - & $\begin{array}{l}\text { 情報通信工事業法法 } \\
\text { 第2条8 }\end{array}$ \\
\hline & 消防 & & & & & & -0 & $\begin{array}{c}\text { 消防施設工事業法 } \\
\text { 第111条(1) }\end{array}$ \\
\hline
\end{tabular}

凡例

コーディネーション

$\mathrm{O}:$ 作成、捺印 0 : 作成支援、捺印

機械: ガス、給排水、換気、暖房、エレベーター

（出所 : 法条項に基づいて筆者作成）

\section{（2）監理業務}

韓国の建築士法における監理業務は建築物、建築設備又は工作物 が設計図書の内容通り施工されているかを確認し、品質管理、工事 管理と安全管理について指導. 監督寸る業務である。建設技術振興法 施行令第 104 条 1 項によると、監理者は技術士、建築士、または 9 年以上の実務経験を持つ技士であることが規定されている。したが って、建築一般と機器設備の監理業務は、建築士とすべての技術士 が担当できる。しかし、高層建築物の構造に関しては、必ず構造技 術士が監理業務に参加しなければならない。電気工事と消防工事の 監理は電気技術士と消防技術士がそれぞれ担当しなければならない。 通信工事は情報通信工事業法第 2 条に通信工事が建築士法第 4 条に 該当する建築工事に含まれる場合、建築一般監理 (施工監理)の基準
に従うことが規定されているため、技術士と建築士が行う。監理業 務に関する各主体の担当範囲を整理すると表 8 になる。

\begin{tabular}{|c|c|c|c|c|c|c|c|c|}
\hline & & 建筑士 & $\begin{array}{l}\text { 建築構造 } \\
\text { 伎通士 }\end{array}$ & $\begin{array}{l}\text { 電気設備 } \\
\text { 技術 }\end{array}$ & 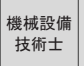 & $\begin{array}{l}\text { 情转通信 } \\
\text { 技行士 }\end{array}$ & $\begin{array}{l}\text { 消防 } \\
\text { 技逨士 }\end{array}$ & 根拠法令 \\
\hline \multirow{6}{*}{ 監理 } & 建築一般 & & $\bigcirc$ & $\bigcirc$ & $\bigcirc$ & O & 0 & $\begin{array}{c}\text { 建設技術管理法 } \\
\text { 第54条 }\end{array}$ \\
\hline & 構造 & 0 & $\triangle$ & - & - & - & - & $\begin{array}{l}\text { 建築法施行令 } \\
\text { 第91条の3(5) }\end{array}$ \\
\hline & 電気 & - & - & $\bigcirc$ & - & - & - & $\begin{array}{l}\text { 電力技術管理法 } \\
\text { 第12条(1) }\end{array}$ \\
\hline & 機械 & 0 & 0 & 0 & 0 & 0 & 0 & $\begin{array}{l}\text { 建設技術管理法 } \\
\text { 第54条 }\end{array}$ \\
\hline & 通信 & 0 & 0 & 0 & 0 & 0 & 0 & $\begin{array}{l}\text { 情報通信工事業法 } \\
\text { 第2条の9 }\end{array}$ \\
\hline & 消防 & & - & - & - & - & 0 & $\begin{array}{l}\text { 消防施設工事業法 } \\
\text { 第16条 }\end{array}$ \\
\hline \multicolumn{9}{|c|}{ コーディネーション } \\
\hline
\end{tabular}

（出所：法条項に基づいて筆者作成）

\section{（3）施工業務}

工事の施工範囲は、建設業免許登録の内容に応じて分類される。 総合工事業免許を持つ業者は総合工事のみ、専門工事業免許を持つ 業者は機械設備工事をはじめとする専門工事のみを行う。電気、通 信、消防工事は各々の電気工事業、通信工事業、消防施設工事業免 許を持つ業者のみ行うことができる。施工業務に関する各主体の担 当範囲を整理すると表 9 になる。

表 9 施エの主体とコーディネーション

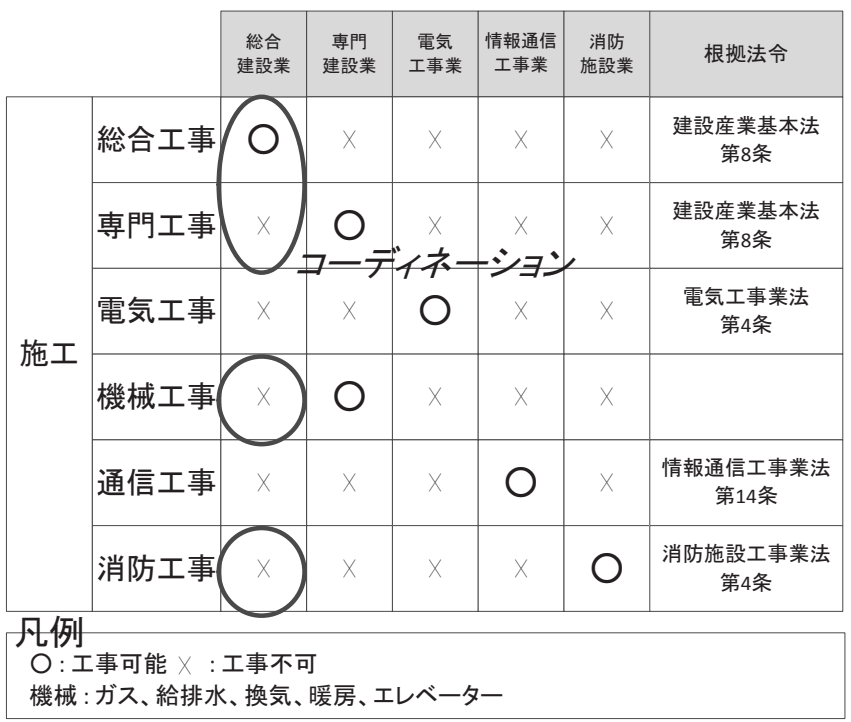

（出所：法条項に基づいて筆者作成）

4-2 業務のコーディネーション

電気と通信工事が分離発注され、各々の工事に関連する設計と監 理を担当する主体も多様になる場合、それらの業務を確認、調整す るコーディネーション業務が重要になる。本節では、コーディネー 


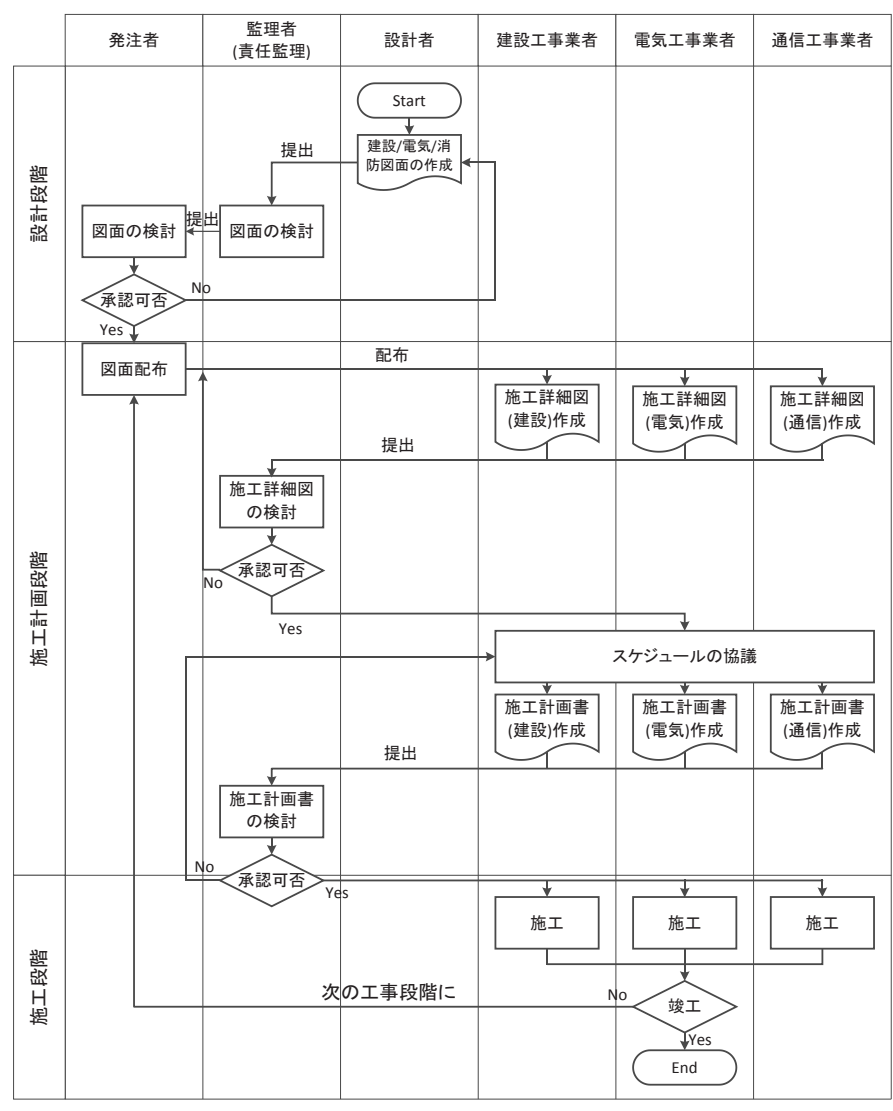

図 6 大規模公共エ事におけるコーディネーションのプロセス

(出所 : 法条項に基づいて筆者作成)

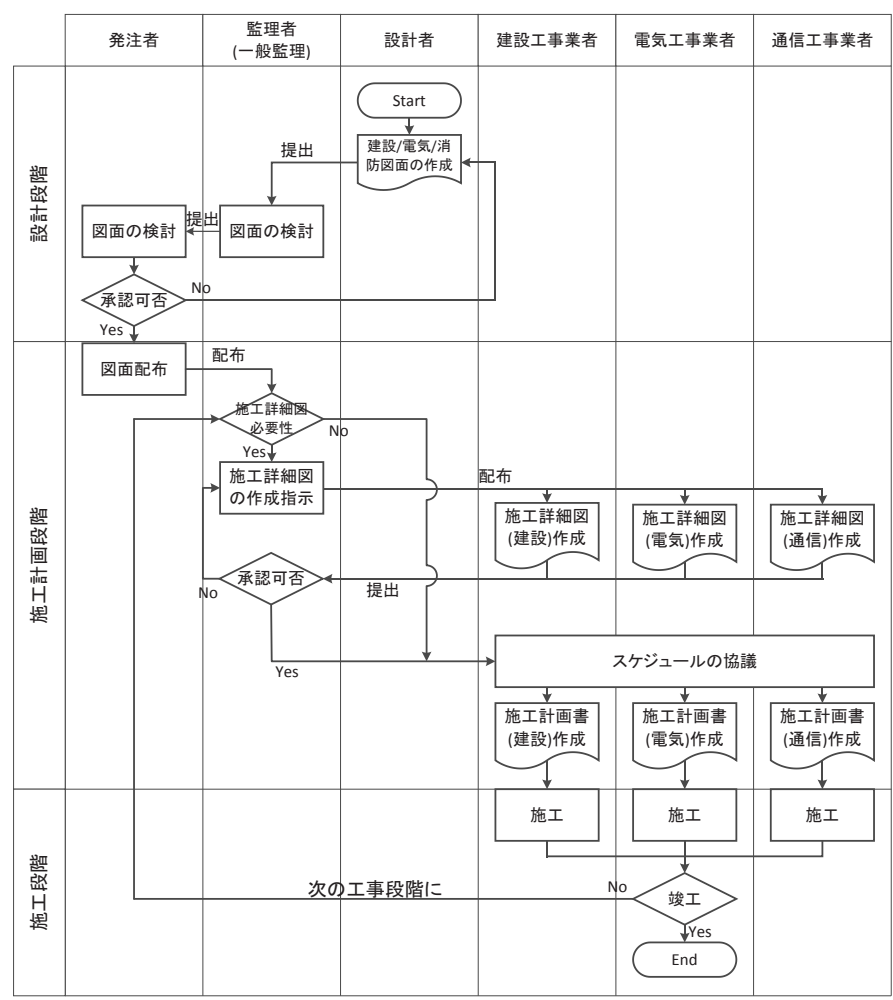

図 7 一般工事におけるコーディネーションのプロセス

(出所 : 法条項に基づいて筆者作成) ション業務を担当する主体とコーディネーションのプロセスを分析
する。

(1) コーディネーションの主体

建築士は、すべての図面を確認、検討し、捺印することになって いるため(建築士法 21 条)の設計のコーディネーション業務は建築 士が行うことになる(表 7)。監理に関しては、ほとんどの工事につ いて建築士が監理業務を行うことができるが、電気工事と消防工事 は別途の技術士が必要である(表 8)。したがって、監理員が三人必 要になる。この場合、建設技術管理法第 28 条 7 項により、総括監理 者を指定することができ、総括監理者は監理員の業務コーディネー ションを行う。一般的には、建築一般を監理することができる建築 士が担当監理者になる。施工においては、総合工事業者が自分の下 請業者である専門工事業者と消防工事業者に対するコーディネーシ ヨンを行う(表 9)。しかし、電気工事と通信工事は分離発注されて いるため、それらの工事を担当する工事業者とのコーディネーショ ンを総合工事業者が行うことはできない。

（2）コーディネーションのプロセス

韓国では、1990 年から一般監理 (工事監理) と検測監理の監理制度 を導入されたが、橋梁崩壊などの事故が発生したため、1994 年大規 模公共工事における監理者に発注者の権限と責任の一部を渡寸責任 監理制度が導入された ${ }^{18)}$ 注2)。韓国における 200 億ウォン以上の大 規模公共工事 (以下、大規模公共工事) と 200 億ウォン未満の公共工 事及び民間工事 (以下、一般工事)の施工に至るまでのプロセスを、 図 6 と図 7 に示す。韓国における大規模公共工事と一般工事は参加 する監理者とプロセスが異なる。大規模公共工事では責任監理が参 加し、一般工事では一般監理が参加する。責任監理と一般監理は施 工に関する業務と責任の範囲が異なる。具体的には、責任監理は一 般監理の権限と業務に加えて発注者の監督権限を代行する ${ }^{19)}$ 。

建設プロジェクトの施工が開始されるまでの期間は、設計図書が 作成される設計段階と、施工のための詳細図作成及びスケジュール を決める施工計画段階の 2 段階に分けられる。まず、建設技術管理 法第 23 条 2(2)項によると、設計段階では建築士と多様な技術士が作 成した図面を監理者に提出し、監理者はこの図面の整合性をチェッ クし、発注者に報告する。発注者は必要によって修正指示を出す。

大規模公共工事の施工計画段階では、建設技術管理法第 23 条 2(3) 項によって、建設工事、電気工事、通信工事を担当寸る各工事業者 が工事段階ごとに要求される施工詳細図を作成し、監理者(責任監 理)に提出する。監理者(責任監理) は施工詳細図について検討、承認 する。施工詳細図が承認されると、各工事業者は工事日程を協議す る。協議された工事日程を施工計画書として作成し、監理者(責任監 理)に提出する。建設技術管理法施行令第 105 条(1)によって監理者 (責任監理) は施工計画を検討、承認する。承認された施工計画に基 づいて、各工事業者は施工を行い、工事が完成するまで、決められ た工事段階ごとに施工詳細図と施工計画書作成を繰り返す (図 6)。

一般工事の施工計画段階において施工詳細図は、建築法 25 条(4)の 規定により監理者 (一般監理) が必要と判断した場合にのみ作成する。 また、監理者 (一般監理)が施工詳細図の作成を指示した場合、監理 者 (一般監理) は作成された施工詳細図を確認、検討しなければなら ない(建築法 24 条)。その後、各事業者間の工事日程の協議が行われ、 施工計画書を作成するが、監理者 (一般監理)の確認を義務化する法 条項はない。したがって、一般工事における施工コーディネーショ 
ンは分離発注と言いながら、総合工事業者が行うことになる。

\section{5. まとめ}

本稿では、韓国を対象とし、分離発注のしくみと各法律上の差を 明確にし、設計と監理、施工に関する業務を担当する主体とコーデ イネーションを担当する主体に関する分析を行い、発注方式として の矛盾点を指摘した。

韓国では 1970 年代から専門工事の品質確保のため、電気工事と通 信工事に対する分離発注を義務化している。しかし、工事に関する 各法律の規定は統一基準で整理されていない。設計、監理、施工に 関するコーディネーションは、大規模公共工事の場合、監理者(責任 監理)が主に行っているが、一般工事の場合、分離発注であるにもか かわらず、総合工事業者が施工コーディネーションを行っている。

以上の分析結果をまとめると、韓国の一般工事における分離発注 は電気工事業者、通信工事業者が発注者と契約を結んでいるため、 分離発注の定義には合っているが、そのコーディネーションを総合 工事業者が行っているという矛盾が発生している。つまり、これは 管理費 (Attendance Fee)がない NSC 制度と類似した片務的な構造で ある。

本研究では、韓国の法律の項目のみに着目して分離発注のしくみ とコーディネーション問題を検討したという限界がある。今後は実 態を把握するため、実プロジェクトを対象として分離発注の全体的 な状況と責任配分の構造を分析することが課題として挙げられる。

\section{謝辞}

この研究は、JSPS 科研費 23246105 (基盤 A、建設プロジェクトの 発注·契約方式と品質確保のしくみに関する国際比較研究、代表 : 古 阪秀三）の助成を受けている。

\section{参考文献}

1) He Zhi: Risk management for overseas construction projects, International Journal of Project Management Vol. 13, No. 4, pp.231-237, 1995.8

2) Thomas E. Uher: Risks in subcontracting: Subcontract conditions, Construction Management and Economics, Vol. 9, pp.495-508, 1991

3) Jasper Mbachu: Conceptual framework for the assessment of subcontractors' eligibility and performance in the construction industry, Construction Management and Economics, Vol. 26, No.5, pp.471-484, 2008.5

4) John Murdoch, et al: Construction Contracts: Law and Management 4th Edition, Taylor \& Francis, p.283, 2008

5）社団法人建設業連合会制度委員会：コストオン・指定下請工事及び性能 発注に関する実態調査報告書，報告書，pp. 36-37, 2013.3

6）趙宰庸、他：建設プロジェクトにおける指定下請制度に関する国際比較 研究、日本建築学会、第 29 回建築生産シンポジウム論文集, pp. 149-156, 2013. 7

7) Su-Kyung Lee: A Study on Legalization of Separate Contracting System for Fire Facility Constructions, Fire Science and Engineering, Vol. 23, No.5, pp.43-49, 2009.10

8) Hyo-Jin Kim: Theoretical Consideration About Separate Order for the Electrical Work, The Transactions of The Korean Institute of Electrical Engineers, Vol.60, No.11, pp.2165-2170, 2011.11

9) Jin-Ho Kim: A Study on the Improvement Plan of Construction Site Management in Korea, Journal of the Korea Institute of Building Construction, Vol.2 No.4, pp.137-144, 2002.12
10) Chul-Ki Chang: Efficient Application of Multi-Trade Contract Method to Public Construction Project, Korean Journal of Construction Engineering and Management, Vol.14, No.2, pp.35-44, 2013.3

11) Sang-Bum Kim: A Comparative Study on Korean Compulsory Multiple Prime Contract System, Korean Journal of Construction Engineering and Management, Vol.14, No.2, pp.184-193, 2013.3

12) You-Gyeong Jo, et al: A Study on Win-Win Barriers between Public Clients and General Contractors, Journal of the Architectural Institute of Korea Structure \& Construction, Vol.30, No.2, pp.63-71, 2014.2

13）李俊錫、他：韓国の建築プロジェクトにおける CM 方式の普及過程とそ の意義, 日本建築学会計画系論文集, Vol.75, No. 649, pp. 667-672, 2010. 3

14）李俊錫、他：監理方式の変遷に伴う韓国の建築プロジェクトの品質確 保のしくみの変化, 日本建築学会計画系論文集, Vol. 75, No. 649, pp. 667-672, 2010. 3

15) Jimmie Hinze: Construction Contracts, Irwin McGraw-Hill, pp.13-14, 1993

16) Union Internationale des Architects : UIA Accord on Recommended International Standards of Professionalism in Architectural Practice, p.12, 1999

17）韓国産業人力公団：技術士受験資格<http://www.q-net.or.kr/crf006. $\mathrm{do} ? \mathrm{id}=\mathrm{crf00603 \& gSite}=\mathrm{Q} \& \mathrm{gId}=>$ (参照 2015.2 .17 )

18）李俊錫、他：韓国における設計者および監理者の役割に関する研究, 日本建築学会計画系論文集, Vol.72, No. 621, pp. 101-108, 2007.11

19）韓国国土交通部：一般 (施工) 監理と責任監理の差<http://www.mo lit.go.kr/USR/policyData/m_34681/dtl?id=213>(参照 2015.6.23)

注

注 1）韓国における監理（诂己：ガムリ）業務は日本のものと業務範囲が異

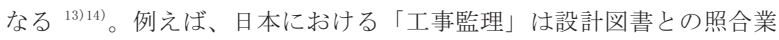
務であるが、韓国における「工事監理」はそれに品質管理・工事管理 及び安全管理業務を加えたものとなっている。本研究は韓国のシステ ムを対象としているため、「監理」という言葉を扱う場合は韓国での 定義に準拠するものとする。

注 2）韓国の公共工事で設計もしくは施工の難易度が高く、特別な管理が 必要であると認めれた場合、発注者は建設事業管理者 (CM) を選定する ことが可能であり(建設技術振興第 39 条)、その場合、建設事業管理者 が責任監理業務も担当していると理解する(建設技術振興第 42 条)。 


\section{A STUDY ON THE SEPARATED CONSTRUCTION PROCUREMENT SYSTEM IN KOREA}

Focusing on the analyzing the legislation of construction in Korea

\section{Jaeyong $\mathrm{CHO}^{*}$ and Shuzo FURUSAKA**}

* Ph. D. Candidate, Dept. of Architecture and Architectural Eng., Graduate School of Eng., Kyoto Univ., M. Eng.
** Prof., Dept. of Architecture and Architectural Eng., Graduate School of Eng., Kyoto Univ., Ph. D. Eng.

Although nominated subcontractor system in which an employer nominates a specialist contractor is widely used all across the world, it does not exist in Korea as separated construction procurement system in which electrical works and communication works are separately nominated is widely used.

The purpose of this study is to clarify the structure of separated construction procurement system and coordination problems that can arise through analysis of legislations related to separated construction procurement in Korea. As the result, this study elucidated that though Korea made it mandatory to separately employ electrical works and communication works to guarantee the quality of specialized works from 1970s, standards of related legal articles are different from one another. Second, the study made clear the principal stakeholders of design work, supervision work and construction work. Lastly, study revealed the contradiction that while responsible supervision is conducted in the coordination regarding design work, supervision work and construction work for public works, general contractors conduct construction coordination in private works.

1. Introduction

2. Korean law system and classifications for construction

There are various business classifications regarding construction work in Korea and laws applied are different according to the business classifications. In addition, unique task domains are classified according to principal agents, and technicians of various industries such as electricity, communication, firefighting and machinery in addition to registered architects participate in construction projects.

3. System of separated construction procurement in legislation

This study analyzed articles of laws related to separated construction procurement and as the result, clarified legal grounds for separated procurement to be applied and separated construction procurement system. And we also attempt to clarify the difference in each electricity, communication, firefighting and machinery works by a detailed analysis of the separated construction procurement clauses of each of the legislation in Korea for system, construction consent and punishment.

4. Analysis of stakeholders for each work and coordination problem

We elucidated the principal agents of design, supervision and construction work of construction projects in Korea and pointed out the contradictory problems of construction coordination taking place in private construction works.

\section{Conclusion}

This Paper study also elucidated the principal agents of design, supervision and construction work of construction projects in Korea and pointed out the contradictory problems of construction coordination taking place in private construction works. 